\title{
Analisis Kinerja Campuran Aspal Beton (AC-BC) Menggunakan Liquid Asbuton Dengan Penambahan Serpih Sampah HDPE (High Density Polyethylene)
}

\author{
Daud Nawir ${ }^{1}$, Achmad Zultan Mansur ${ }^{2 *}$ \\ ${ }^{1,2}$ Universitas Borneo Tarakan (UBT), Jl. Amal Lama no. 1, Tarakan 77123 Indonesia, e-mail: \\ Email: achmadzultan@gmail.com
}

Received 14 Februari 2020; Reviewed 26 April 2020; Accepted 05 Juni 2020

Journal Homepage: http://jurnal.borneo.ac.id/index.php/borneoengineering

DOI: https://doi.org/10.35334/be.v4i1.1281

\begin{abstract}
The use of asphalt (Liquid asbuton) as a road pavement material can be an economical and efficient choice for road construction and maintenance because, in addition to being cheaper and having better work abilities compared to other types of buton asphalt, a new step is carried out by using Asbuton liquid in a hot mix. One of the materials used is high-density polyethylene (HDPE) plastic waste. The ideal plastic prohibition needs to be balanced with waste management and financial incentives to change the habits of consumers and industry players. This research was conducted to determine the effect of using HDPE type plastic as an addition to the Asphalt Layer mixture Concrete (Laston) in terms of Marshall characteristics by using liquid asbuton and the level of plastic addition used was $2 \%$, $4 \%$, and $6 \%$ The results achieved were the addition of plastic waste flakes into the asphalt concrete mixture $A C-B C$ can save asphalt $6 \%$ to the weight of asphalt The characteristics of the AC-BC mixture can be explained that with the addition of plastic waste flakes, stability will rise, flow decreases, Marshal Quotient (MQ) increases, VIM decreases, VMA decreases, VFB increases with increasing levels of effective asphalt, remaining marshall stability can be reached above $90 \%$, and the cavity in the cam Puran at the refusal density can be achieved in the range greater than $2 \%$.
\end{abstract}

Key Words: $A C-B C, H D P E$, liquid asbuton

\begin{abstract}
Abstrak
Penggunaan aspal (Liquid asbuton) sebagai bahan perkerasan jalan dapat menjadi pilihan yang ekonomis dan efisien untuk pembangunan dan pemeliharaan jalan, karena selain harganya yang lebih murah dan mempunyai work ability yang lebih baik dibanding jenis aspal buton lainnya, maka dilakukan suatu langkah baru yaitu dengan penggunaan Liquid asbuton dalam campuran aspal panas (Hot mix). Salah satu material yang digunakan adalah limbah plastik jenis high density polyethylene (HDPE). Pelarangan plastik idealnya perlu diimbangi dengan pengelolaan sampah dan insentif finansial untuk mengubah kebiasaan konsumen dan pelaku industri. Penelitian ini dilakukan untuk mengetahui pengaruh dari penggunaan plastik jenis HDPE sebagai penambahan dalam campuran Lapis Aspal Beton (Laston) ditinjau dari karakteristik Marshall dengan menggunakan liquid asbuton dan kadar penambahan plastik yang digunakan adalah 2\%, 4\%, dan 6\%. Hasil yang dicapai adalah dengan penambahan serpih sampah plastik kedalam campuran aspal beton AC-BC dapat menghemat aspal 6\% terhadap berat aspal. Karakteristik campuran AC-BC dapat dijelaskan bahwa dengan penambahan serpih sampah plastik, Stabilitas akan naik, Flow menurun, Marshal Quotien (MQ) bertambah, VIM mengecil, VMA mengecil, VFB bertambah seiring dengan bertambahnya kadar aspal efektif, Stabilitas marshall sisa dapat dicapai diatas $90 \%$, dan rongga dalam campuran pada kepadatan membal (refusal) dapat dicapai pada kisaran lebih besar dari $2 \%$.
\end{abstract}

Kata kunci: $A C-B C, H D P E$, liquid asbuton 


\section{Pendahuluan}

Aspal Buton atau yang lazim dikenal dengan asbuton merupakan produk asli dalam negeri yang hanya ditemukan di pulau Buton Sulawesi Tenggara. Dengan SDA material yang melimpah namun belum dimanfaatkan secara maksimal oleh pemerintah. Pemanfaatan aspal minyak yang berasal dari barang impor masih mendominasi di dunia konstruksi jalan hal ini tentunya bisa menghemat penggunaan uang negara jika memaksimalkan penggunaan aspal buton. Wujud Aspal Buton yang merupakan bahan tambang berbentuk batu-batuan yang mengandung bitumen dengan pori-pori kandungan aspal alam. Dari setiap lokasi penambangan asbuton memiliki variasi kandungan bitumen di dalam pori-pori batuan. Maka perlu perhatian khusus agar pemanfaatan asbuton mampu menggantikan aspal minyak impor demi optimalisasi SDA negeri kita. Adapun terjadinya retak pada pekerjaan Laston sering terjadi pada perkerasan jalan terutama pada jalan-jalan berlalu lintas berat hal ini juga disebabkan oleh nilai VIM yang sering melampaui ambang atas nilai VIM laboratorium. Jika kadar aspal dinaikkan VIM akan mengecil, tetapi VIM yang kecil $(<3 \%)$, menyebabkan deformasi plastis, karena aspal dalam campuran terlalu besar. Apabila kadar aspal diturunkan, menyebabkan VIM menjadi besar yang mengancam retak pada jalan (Zultan, 2019). Plastik merupakan material yang sangat akrab dalam kehidupan manusia dan sudah dianggap sebagai bahan pokok kebutuhan rumah tangga ataupun domestik sehingga keberadaan sampah plastik semakin meningkat (Kurniawan, 2014). Pelarangan plastik bagi masyrakat perlu disiasati dengan mendaur ulang agar menjadi material ekonomis yang bisa dimanfaatkan dalam dunia konstruksi. Pada penelitian ini ada upaya untuk mengurangi kadar aspal dengan menambah serpih sampah plastik kedalam campuran aspal Laston. Bahan plastik yang dimaksudkan dalam penelitian ini adalah bahan plastik sampah dari jenis High density polyethylene (HDPE) dengan asumsi bahwa plastik baru dengan plastik bekas adalah sama secara spesifik.

Ada beberapa penelitian terdahulu yang kami jadikan bahan acuan pada penelitian ini. Pemanfaatan serpih plastik jenis LDPE yang hasilnya pengaruh penambahan serpih sampah plastik terhadap karakteristik campuran aspal beton (AC-BC) dapat menghemat aspal $2 \%$ terhadap berat aspal serta stabilitas akan naik, Flow menurun, Marshal Quotien (MQ) bertambah, VIM mengecil, VMA mengecil, VFB bertambah seiring dengan bertambahnya kadar aspal efektif (Zultan, 2017). Pemanfaatan material daur ulang menggunakan bongkaran aspal (RAP) dicampurkan Pasir Pantai Dengan Serpih Sampah Plastik jenis LDPE, hasilnya menunjukkan bahwa penggunaan material bongkaran sebesar $10 \%$ bersama dengan pasir pantai dalam kisaran $0 \%-20 \%$, dalam campuran aspal beton AC-BC cenderung menaikkan kinerja stabilitas campuran. Terhadap VIM dan VMA, cenderung menghasilkan nilai yang menurun. Nilai Flow yang diperoleh dari hasil hubungan dengan proporsi campuran bongkaran aspal dan pasir pantai, memperlihatkan bahwa penggunaan bongkaran aspal yang tetap yaitu $20 \%$ dengan penambahan pasir pantai akan menghasilkan nilai Flow yang semakin besar (Zultan dkk, 2018).

Pemanfaatan Limbah Plastik LDPE yang menyelimuti agregate pada lapisan aus laston menghasilkan nilai stabilitas tertinggi yaitu $2498,39 \mathrm{~kg} / \mathrm{cm} 2$, pada kadar aspal sebesar $4 \%$ dan plastik 6\%. Untuk melihat kinerja durabilitas campuran aspal beton digunakan indikator Index of Retained Strength (IRS) (Setrayani dkk, 2018). Pemanfaatan serpih plastic jenis LPDE enggunakan liquid asbuton dalam campuran Lapis Aspal Beton (Laston), hasil yang dicapai adalah dengan penambahan serpih sampah plastik kedalam campuran aspal beton AC-BC dapat menghemat aspal $3 \%$ terhadap berat aspal. Karakteristik campuran AC-BC dapat dijelaskan bahwa dengan penambahan serpih sampah plastik, Stabilitas akan naik, Flow menurun, Marshal Quotien (MQ) bertambah, VIM mengecil, VMA mengecil, VFB bertambah seiring dengan bertambahnya kadar aspal efektif, Stabilitas marshall sisa dapat dicapai diatas $90 \%$, dan rongga dalam campuran pada kepadatan membal (refusal) dapat dicapai pada kisaran lebih besar dari $2 \%$ (Zultan dan Nawir, 2019). 
Dipilihnya limbah plastik HDPE karena Plastik jenis ini sifatnya sebagai plastik kemasan sekali pakai yang sering ada disekitar kita dan volume sampah plastik HDPE juga cukup mudah di temui di lingkungan serta sangat sulit terurai secara alami, seperti kantong belanja, botol minuman, detergen, botol shampo, dan semisalnya. .Pada penelitian ini merupakan kelanjutan dari penelitian sebelumnya yaitu menggunakan Liquid Asbuton pada campuran beton AC-BC dengan variasi penambahan plastik berjenis HDPE. Pada penelitian terdahulu belum pernah dilakukan penggunaan campuran plastik berjenis HDPE yang kadar penambahan plastik yang digunakan adalah $2 \%, 4 \%$, dan $6 \%$. Untuk mengetahui sejauh mana pengaruhnya terhadap campuran aspal beton (AC-BC) maka dilakukan pengujian terhadap karakteristik aspal beton yaitu stabilitas dan Marshal Quotien (MQ) (RSNI M-01-2003). Tujuan penelitian ini yaitu untuk mendapatkan karakteristik Marshall dari campuran Aspal beton AC-BC yang menggunakan Liquid asbuton terhadap pengaruh penambahan variasi Limbah; Mengetahui pengaruh limbah plastik sebagai bahan substitusi aspal atas pengaruhnya terhadap karakteristik campuran aspal beton AC-BC; Mengetahui prosentase penghematan aspal pada campuran aspal beton AC-BCatas substitusi penggunaan plastik yang berjenis HDPE terhadap aspal

\section{Metode Penelitian}

Tahap awal dari penelitian ini yaitu persiapan melakukan pengumpulan material dan juga persiapan alat-alat yang akan dipergunakan yang berkaitan dengan pengujian. Kemudian dilakukan pengujian terhadap material/bahan penyusun campuran beton aspal yaitu aspal, agregat dan plastik HDPE, yang dimaksudkan untuk mengetahui sifat dan karakteristik material/bahan tersebut (R. Anwar dan Siegfried, 2012). Material bahan dan alat yang telah siap dilanjutkan pembuatan benda uji yaitu pembuatan proporsi agregat sesuai gradasi, rancangan benda uji dan pengujian, serta pengaruhnya dengan nilai KAO campuran. Setelah dibuat benda uji berdsarkan variasi kadar aspal maka dilakukan kembali pengujian Marshall untuk mendapatkan nilai karakteristik pencampuran dan hasil Marshall Immersion Test dari kedua campuran tersebut (R. Anwar, 2002). Hasil akhir dibuat benda uji berdasarkan nilai KAO dalam campuran aspal beton dengan penambahan variasi serpih plastic berjenis HDPE.

Lokasi penelitian ini dilakukan di Laboratorium Jalan, Jurusan Teknik Sipil, Fakultas Teknik Sipil, Universitas Borneo Tarakan. Agregat kasar, agregat halus dan filler yang digunakan dalam penelitian ini bersumber dari PT. Krist Inti Perkasa yang berdomisili di Kota Tarakan. Diperoleh dari hasil pengolahan mesin pemecah batu (Stone Crusher) untuk mendapatkan agregat yang memenuhi persyaratan ukuran yang diperlukan sesuai spesifikasi. Standar pengujian yang digunakan yaitu untuk pengujian Job mix design didasarkan pada SNI 03-1737-1989 (Tata Cara Pelaksanaan Lapisan Beton LASTON untuk Jalan Raya) sedangkan untuk pengujian marshall menggunakan SNI 06-2489-1991 (Metode Pengujian Campuran Aspal dengan Alat Marshall) (Bina Marga, 1999)

Adapun bagan alir penelitian seperti yang di tampilkan pada gambar 1 dibawah ini 


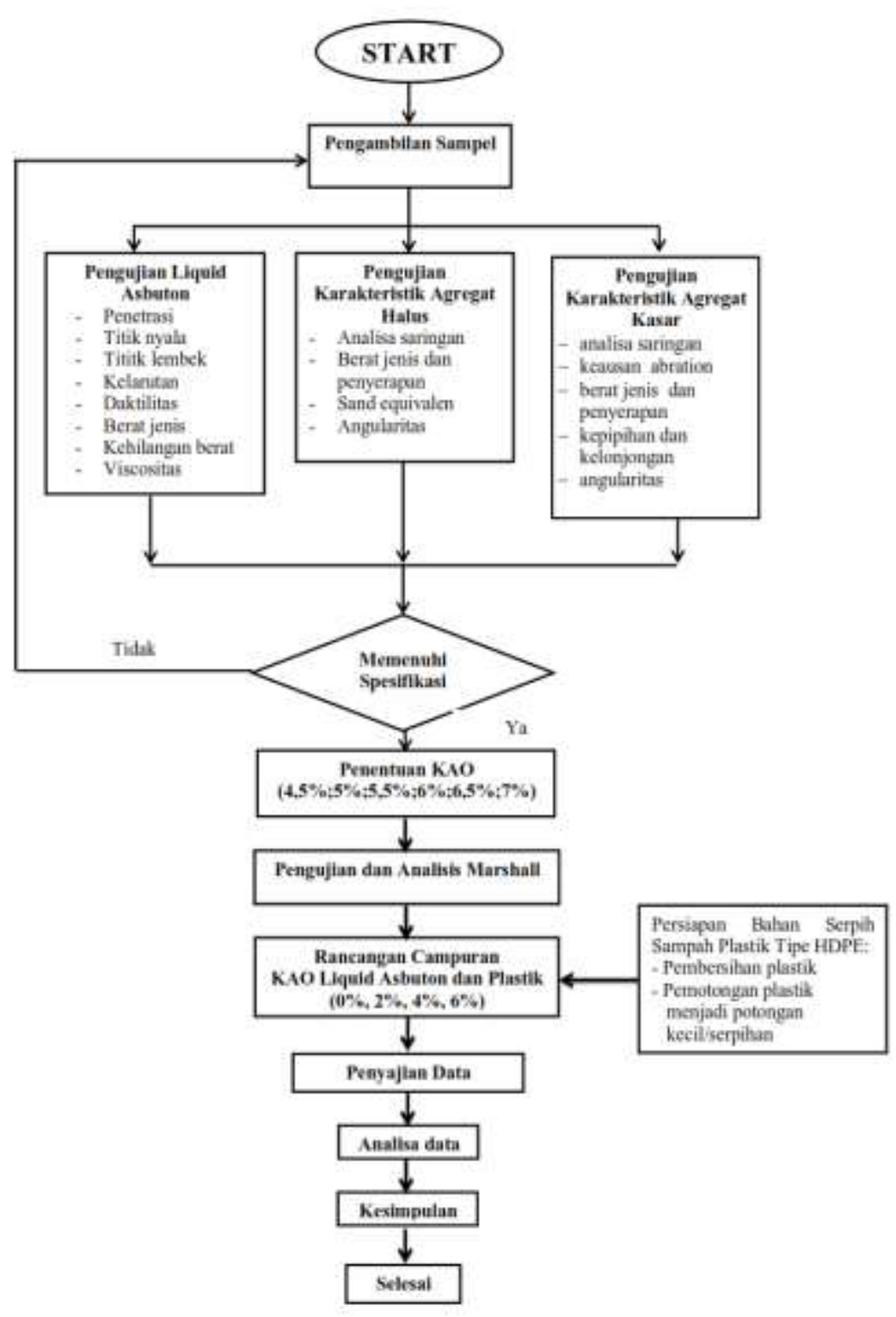

Gambar 1. Bagan alir penelitian

\section{Hasil dan Pembahasan}

\subsection{Hasil Pengujian Karakteristik Liquid Asbuton}

Liquid Asbuton merupakan hasil dari ekstraksi batuan aspal dari Buton, melalui pengembangan teknologi dan dapat digunakan sebagai bahan aspal dalam campuran aspal beton. Pengujian fisik dilakukan terhadap Liquid asbuton untuk mengevaluasi sifat-sifat fisik dari bitumen asbuton (Liquid) yang berkaitan dengan kinerjanya sebagai komponen campuran beraspal . Hasil pengujian fisik Liquid asbuton diperlihatkan pada Tabel 1. Dari hasil pengujian Foto SEM dan EDX pada sampel $100 \%$ Liquid asbuton dapat diketahui susunan unsur-unsur kimia Liquid asbuton aitu C (Carbon), O (Oksigen), Al ( Aluminium), Si (Silika), S (Sulfur), Ca (Calsium) melalui suatu proses persenyawaan kimia sehingga membentuk senyawa $\mathrm{Al}_{2} \mathrm{O}_{3}, \mathrm{SiO}_{2}, \mathrm{SO}_{3}, \mathrm{CaO}$ (Zultan dan Nawir, 2019). 
Tabel 1. Hasil pengujian fisik Liquid Asbuton

\begin{tabular}{|c|c|c|c|c|c|}
\hline \multirow{3}{*}{ Pengujian } & \multirow{3}{*}{ Metode } & \multirow{3}{*}{$\begin{array}{c}\text { Hasil } \\
\text { Uji } \\
\text { Liquid } \\
\text { Asbuton }\end{array}$} & \multicolumn{3}{|c|}{ Yang disyaratkan } \\
\hline & & & \multicolumn{2}{|c|}{ Modifikasi } & \multirow[t]{2}{*}{ Satuan } \\
\hline & & & Min & Max & \\
\hline Penetrasi sebelum Kehilangan berat & SNI. 06 - $2456-1991$ & 56,2 & 40 & 60 & $0,1 \mathrm{~mm}$ \\
\hline Titik lembek & SNI. 06 - $2434-1991$ & 58,5 & 55 & - & ${ }^{\circ} \mathrm{C}$ \\
\hline Daktilitas ( $25 \mathrm{C}, 5 \mathrm{~cm} /$ menit ) & SNI. 06 - $2432-1991$ & 94 & 50 & - & $\mathrm{Cm}$ \\
\hline $\begin{array}{l}\text { Kelarutan dalam Triclor Ethylen } \\
\left(\mathrm{C}_{2} \mathrm{HCL}_{3}\right)\end{array}$ & SNI. 06 - $2438-1991$ & 93 & 90 & - & $\%$ Berat \\
\hline Titik nyala ( COC ) & SNI. 06 - $2433-1991$ & 233 & 225 & - & ${ }^{\circ} \mathrm{C}$ \\
\hline Berat Jenis & SNI. 06 - $2441-1991$ & 1,12 & 1 & - & \\
\hline $\begin{array}{l}\text { Kehilangan berat } 163 \mathrm{C}, 5 \text { jam } \\
\text { (thin film oven test ) }\end{array}$ & SNI. 06 - $2440-1991$ & 1,63 & - & 2 & $\%$ Berat \\
\hline Penetrasi setelah kehilangan berat & SNI. 06 - $2434-1991$ & 85,43 & - & - & $\%$ Asli \\
\hline $\begin{array}{l}\text { Viscositas } 170 \text { Cst } \\
\text { ( Temp. pencampuran ) }\end{array}$ & SNI. 03 - $6721-2002$ & 165 & - & - & ${ }^{\circ} \mathrm{C}$ \\
\hline $\begin{array}{l}\text { Viscositas } 280 \text { Cst } \\
\text { ( Temp. pemadatan ) }\end{array}$ & SNI. 06 - $6721-2002$ & 143 & - & - & ${ }^{\circ} \mathrm{C}$ \\
\hline
\end{tabular}

Tabel 2. Hasil pengujian fisik Liquid Asbuton tambah Plastik

\begin{tabular}{|c|c|c|c|c|c|c|c|}
\hline \multirow{2}{*}{ Pengujian } & \multirow{2}{*}{ Metode } & \multicolumn{3}{|c|}{$\begin{array}{c}\text { Hasil Uji Liquid } \\
\text { Asbuton tambah } \\
\text { Plastik }\end{array}$} & \multicolumn{3}{|c|}{$\begin{array}{l}\text { Yang disyaratkan } \\
\text { Asbuton }\end{array}$} \\
\hline & & $2 \%$ & $4 \%$ & $6 \%$ & Min & Max & \\
\hline $\begin{array}{l}\text { Penetrasi sebelum Kehilangan } \\
\text { berat }\end{array}$ & SNI. 06 - 2456 - 1991 & 56,4 & 52,2 & 50,7 & 40 & 60 & $\begin{array}{l}0,1 \\
\mathrm{~mm}\end{array}$ \\
\hline Titik lembek & SNI. 06 - $2434-1991$ & 58 & 60 & 62 & 55 & - & ${ }^{\circ} \mathrm{C}$ \\
\hline Daktilitas ( $25 \mathrm{C}, 5 \mathrm{~cm} /$ menit ) & SNI. 06 - $2432-1991$ & 94 & 92 & 88 & 50 & - & $\mathrm{Cm}$ \\
\hline $\begin{array}{l}\text { Kelarutan dalam Triclor } \\
\text { Ethylen }\left(\mathrm{C}_{2} \mathrm{HCL}_{3}\right)\end{array}$ & SNI. 06 - 2438 - 1991 & 92 & 90 & 88 & 90 & - & $\begin{array}{c}\% \\
\text { Berat }\end{array}$ \\
\hline Titik nyala ( COC ) & SNI. 06 - $2433-1991$ & 245,7 & 235,5 & 228,8 & 225 & - & ${ }^{\circ} \mathrm{C}$ \\
\hline Berat Jenis & SNI. 06 - 2441 - 1991 & 1,16 & 1,15 & 1,14 & 1 & - & \\
\hline $\begin{array}{l}\text { Kehilangan berat } 163 \mathrm{C}, 5 \\
\text { jam } \\
\text { (thin film oven test ) }\end{array}$ & SNI. 06 - 2440 - 1991 & 1,6 & 1,72 & 1,94 & - & 2 & $\begin{array}{c}\% \\
\text { Berat }\end{array}$ \\
\hline $\begin{array}{l}\text { Penetrasi setelah kehilangan } \\
\text { berat }\end{array}$ & SNI. 06 - 2434 - 1991 & 86,54 & 83,47 & 80,42 & - & - & $\%$ Asli \\
\hline $\begin{array}{l}\text { Viscositas } 170 \text { Cst } \\
\text { ( Temp. pencampuran ) }\end{array}$ & SNI. 03 - $6721-2002$ & 168 & 170 & 175 & - & - & ${ }^{\circ} \mathrm{C}$ \\
\hline $\begin{array}{l}\text { Viscositas } 280 \text { Cst } \\
(\text { Temp. pemadatan })\end{array}$ & SNI. 06 - $6721-2002$ & 148 & 154 & 158 & - & - & ${ }^{\circ} \mathrm{C}$ \\
\hline
\end{tabular}

\subsection{Mix Design Aspal Beton AC-BC}

\subsubsection{Penentuan kadar aspal optimum aspal liquid asbuton}

Untuk mencari kadar aspal optimum dari suatu campuran beraspal dilakukan pengujian dengan metoda Marshall. Pencampuran agregat dan bitumen aspal dilakukan pada temperatur sesuai dengan temperatur masing-masing sesuai dengan temperatur viskositas tiap variasi pencampuran aspalnya, menggunakan pemadat Marshall dengan jumlah tumbukan sebanyak $2 \times 75$. Hasil dari analisis pengujian marshall sebagai parameter karakteristik aspal berupa nilai stabilitas, kelelehan (flow), kepadatan, volume rongga dalam campuran (VIM), volume rongga dalam mineral agregat 
(VMA) dan rongga terisi aspal (VFB) (AASHTO, 1978). Hasil dari pengujian Marshall untuk memperoleh kadar aspal optimun disajikan pada Tabel 3.

Tabel 3. Hasil Pengujian Marshall pada benda uji AC-BC dengan Liquid Asbuton

\begin{tabular}{ccccccc}
\hline $\begin{array}{c}\text { Kadar } \\
\text { Aspal }\end{array}$ & VIM & VMA & VFB & $\begin{array}{c}\text { Stabilitas } \\
(\mathrm{Kg})\end{array}$ & $\begin{array}{c}\text { Flow } \\
\text { mm }\end{array}$ & $\begin{array}{c}\text { Quotient } \\
(\mathrm{Kg} / \mathrm{mm})\end{array}$ \\
\hline 4,50 & 9,78 & 23,43 & 55,45 & 1987,45 & 3,45 & 576,07 \\
5,00 & 5,87 & 20,12 & 60,43 & 2135,72 & 3,65 & 585,13 \\
5,50 & 5,67 & 19,34 & 67,81 & 2187,52 & 3,78 & 578,71 \\
6,00 & 4,89 & 18,80 & 75,82 & 2032,22 & 3,83 & 530,61 \\
6,50 & 3,76 & 17,27 & 80,93 & 1987,27 & 3,95 & 503,11 \\
7,00 & 3,10 & 16,42 & 85,74 & 1996,34 & 3,98 & 501,59 \\
\hline Spesifikasi & $\mathbf{3 , 0} \mathbf{- 5 , 0}$ & $>\mathbf{1 4}$ & $>\mathbf{6 5}$ & $>\mathbf{8 0 0}$ & $\mathbf{2 - 4}$ & Min.250 \\
\hline
\end{tabular}

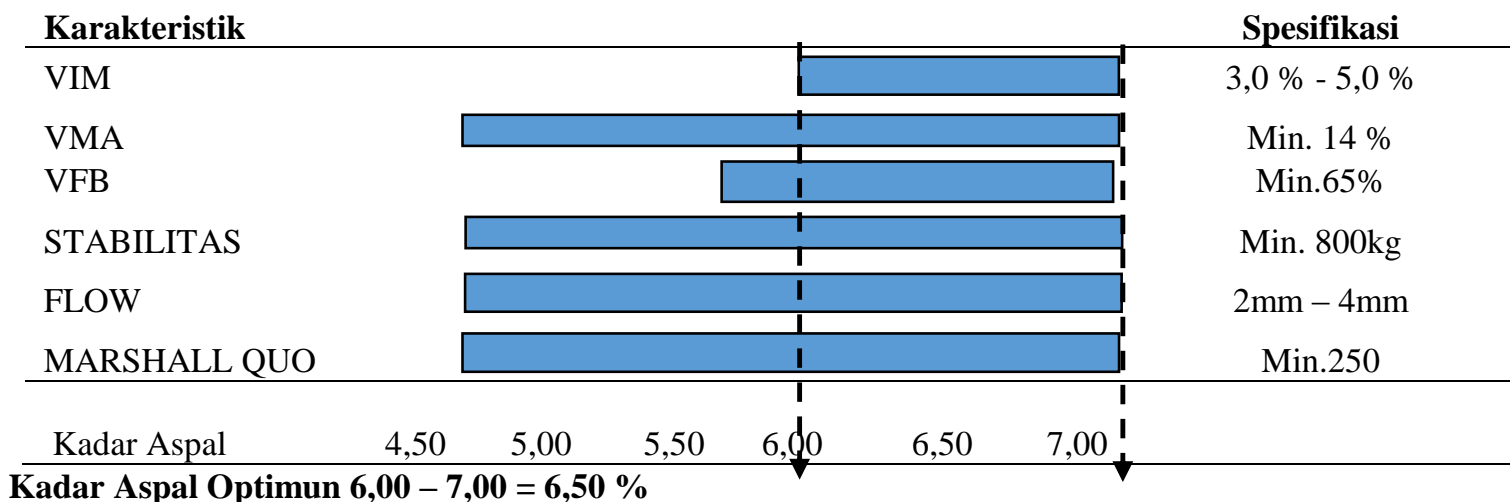

Kadar Aspal Optimun 6,00 - 7,00 = 6,50 \%

\subsubsection{Pemeriksaan Karakteristik Campuran Aspal Beton AC-BC tanpa dan dengan Penambahan Serpih Sampah Plastik melalui Metode Marshall 75 x tumbukan (lalulintas padat)}

Hasil-hasil pemeriksaan seperti yang tercantum dalam tujuan penelitian ini adalah Stabilitas, Flow, Marshal Quotien (hasil bagi marshal), rongga dalam campuran (VIM), rongga diantara agregat (VMA), rongga terisi aspal (VFB), stabilitas marshal sisa setelah perendaman 24 jam pada suhu 60 $\mathrm{C}$, serta kepadatan membal (refusal). Campuran yang mengandung Liquid asbuton memiliki penetrasi dan titik lembek yang lebih rendah, jika dibandingkan dengan campuran tanpa Liquid asbuton, membuat ikatan mortar menjadi lebih kaku sehingga akan menaikkan nilai stabilitas. Hal ini disebabkan bertambahnya mineral filler yang berlebihan sehingga gradasi campuran relatif kelebihan mineral halus yang berfungsi sebagai bahan pengisi yang membentuk ikatan mortar dengan aspal. Pada tabel 4 memberikan gambaran bahwa dengan penambahan serpih sampah plastik kedalam campuran AC-BC, dapat meningkatkan kemampuan campuran dalam menerima beban lalulintas. Hasil-hasil pemeriksaan tersebut dapat dilihat pada tabel 4 .

\section{a. Stabilitas}

Stabilitas merupakan ukuran kemampuan campuran untuk memikul beban lalu lintas sampai terjadi kelelehan plastis. Nilai stabilitas tersebut diukur langsung dari pengujian, pada saat dibebani dengan alat uji Marshall (AASHTO, 1978). Faktor - faktor yang mempengaruhi stabilitas diantaranya adalah gradasi agregat, dan kadar aspal dalam campuran. Campuran yang mengandung Liquid asbuton menyebabkan ikatan mortar dalam campuran belebihan dan selanjutnya akan menyebabkan campuran lebih kaku dan menghasilkan nilai flexibilitas yang kecil 
Tabel 4. Hasil Pengujian Karakteristik Campuran AC-BC tanpa dan Dengan Penambahan Serpih Sampah Plastik

\begin{tabular}{|c|c|c|c|c|c|c|}
\hline \multirow{4}{*}{ No } & \multirow{4}{*}{$\begin{array}{l}\text { Karakteristik } \\
\text { Campuran (AC-BC) }\end{array}$} & \multicolumn{4}{|c|}{ Kadar Aspal Terhadap Campuran (\%) } & \multirow{4}{*}{ Spesifikasi } \\
\hline & & & 6,48 & 6,46 & 6,44 & \\
\hline & & \multicolumn{4}{|c|}{ Kadar Plastik Terhadap Aspal (\%) } & \\
\hline & & $\mathbf{0}$ & 2 & 4 & 6 & \\
\hline 1 & Stabilitas (kg) & 1887,42 & 1967,93 & 2086,09 & 2138,62 & Min. 800 \\
\hline 2 & Flow $(\mathrm{mm})$ & 4,62 & 4,72 & 4,45 & 4,25 & $2-4$ \\
\hline 3 & Marshall Quotient (kg/mm) & 408,53 & 416,93 & 468,78 & 503,20 & Min. 250 \\
\hline 4 & Rongga dalam campuran (VIM) (\%) & 4,76 & 4,67 & 4,45 & 4,10 & $3,0-5,0$ \\
\hline 5 & Rongga dalam Aggregat (VMA) (\%) & 21,45 & 19,63 & 17,61 & 15,52 & Min. 14 \\
\hline 6 & Rongga terisi aspal (VFB) (\%) & 78,74 & 80,45 & 82,43 & 84,69 & Min. 65 \\
\hline 7 & $\begin{array}{l}\text { Stabilitas Marshall sisa (\%) } \\
\text { set. Perendaman } 24 \text { jam, } 60 \mathrm{C}\end{array}$ & 1742.08 & 1855.13 & 1945.89 & 1978.62 & Min. 90 \\
\hline 8 & $\begin{array}{l}\text { Rongga dlm campuran (\%) } \\
\text { pd kepadatan membal (Refusal) }\end{array}$ & 4,52 & 4,65 & 3,84 & 3,40 & Min. 2 \\
\hline
\end{tabular}

Pada gambar 2 menunjukkan pengujian korelasi aspal terhadap plastik (uji Daktilitas dan Penetrasi), ada kecendrungan aspal tidak lagi memenuhi syarat jika proporsi plastik sampai $6 \%$ terhadap berat kandungan aspal. Dengan penambahan serpih sampah plastik kedalam campuran aspal beton AC-BC sangat ideal pada proporsi kandungan plastik $6 \%$ terhadap berat aspal tetapi jika di campur hingga konsentrasi $6 \%$ atau lebih, konstruksi AC-BC cenderung terancam dengan sifat yang kaku yang terancam patah dan retak serta fatik.

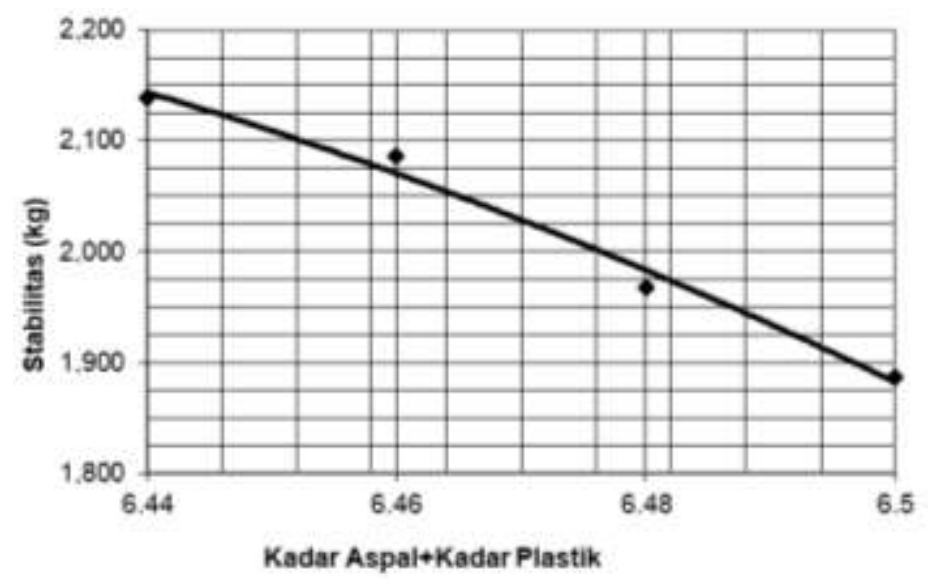

Gambar 2. Hubungan Kadar Plastik + Aspal Terhadap Stabilitas

\section{b. Kelelehan (flow)}

Kelelehan atau flow, merupakan ukuran kelenturan campuran untuk dapat mengikuti deformasi yang terjadi akibat beban lalu lintas tanpa menimbulkan retak dan perubahan volume. Dari hasil analisis Marshall pada tabel 4, nilai kelelehan cenderung turun seiring dengan bertambahnya kadar plastic, hal ini diakibatkan oleh mengerasnya aspal jika plastik tergabung kedalam campuran sehingga membuat butiran menjadi tidak mudah bergeser dan semakin mengurangi kelenturan campuran. Oleh karena itu penelitian ini membatasi kadar plastik sampai dengan $6 \%$ berat terhadap aspal. Walaupun keberadaan plastik di dalam campuran ada kecendrungan mempengaruhi sifat aspal menjadi mengeras, namun batas toleransi atau nilai kelenturan masih jauh dibawah yang 
di syaratkan spesifikasi. Sehingga sifat kelenturan yang dimiliki campuran AC-BC dengan masuknya plastik masih belum berpengaruh negatif terhadap campuran tersebut.

\section{c. Marshall Quotient (MQ)}

Marshall Quotient merupakan rasio antara nilai stabilitas dan nilai kelelehan. Campuran AC-BC dengan nilai stabilitas yang cukup tinggi, mempunyai hasil bagi Marshall yang lebih besar (RSNIM-01-2003). Marshall Quotient juga merupakan indikator terhadap kekakuan campuran secara empiris. Kenaikan nilai MQ dengan penambahan kadar plastik kedalam campuran AC$\mathrm{BC}$,memberikan kontribusi positif terhadap pertambahan nilai stabilitas.

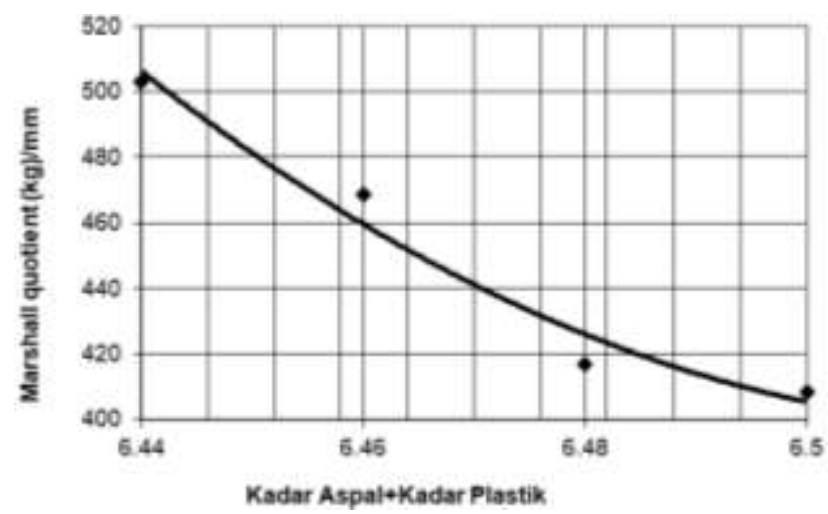

Gambar 3. Hubungan Kadar Plastik + Aspal Terhadap MQ

Pada gambar 3 diatas dengan masuknya plastik kedalam campuran AC-BC mempengaruhi nilai MQ menjadi naik. Dengan masuknya kadar plastik kedalam campuran AC-BC terbukti memperbaiki konstruksi tersebut dari segi MQ. Menurut spesifikasi nilai MQ tidak boleh kurang dari $250 \mathrm{~kg} / \mathrm{mm}$.

\section{d. Rongga dalam campuran beraspal (Voids in Mixture)}

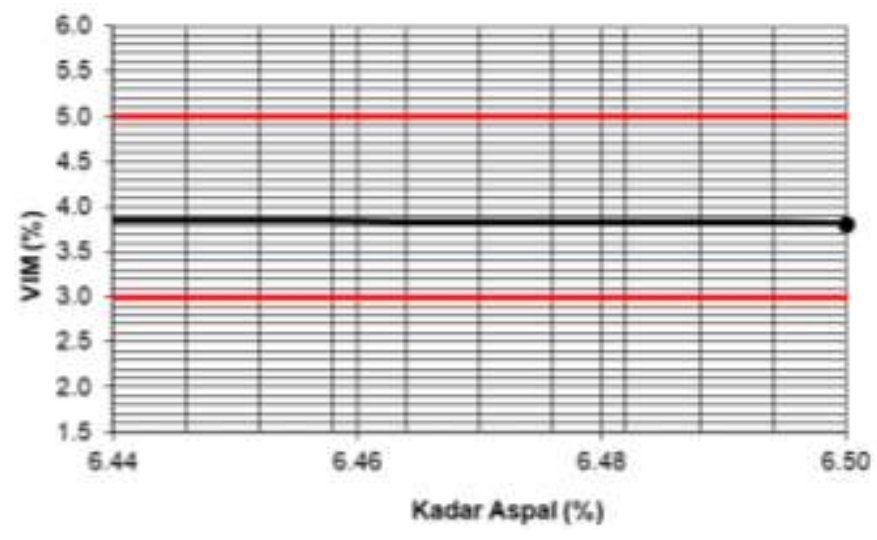

Gambar 4. Hubungan Kadar Plastik + Aspal Terhadap VIM

Kandungan VIM berhubungan dengan keawetan campuran, bilamana nilai VIM terlalu tinggi campuran akan cenderung rapuh, mempunyai kecenderungan retak secara dini (Bina marga, 1999). Sedangkan nilai VIM yang kecil akan meningkatkan ketahanan campuran terhadap pengerasan aspal dan pengelupasan partikel akibat oksidasi, tetapi bila nilai VIM terlalu kecil akan menyebabkan campuran tidak stabil dan kemungkinan terjadi kelelehan plastis yang lebih besar, 
yaitu disebabkan tidak tersedianya ruang yang cukup untuk menampung ekspansi aspal akibat pemadatan lanjutan oleh lalu lintas dan kenaikan temperatur pada perkerasan pada masa pelayanan.

\section{e. Rongga diantara agregat (Void In Mineral Aggregate),}

VMA adalah volume rongga udara diantara butir-butir agregat dalam campuran beraspal dalam kondisi yang padat. VIM dan volume aspal efektif adalah bagian dari VMA (Bina Marga, 1999). Dari hasil pengujian menunjukkan penambahan serpih sampah plastik kedalam campuran AC-BC, memberikan pengaruh terhadap berat isi campuran yang nilainya cenderung bertambah yang mengakibatkan penurunan nilai VMA. Pada Gambar 5 terlihat bahwa campuran dengan menggunakan Liquid asbuton memberikan nilai VMA yang lebih besar Hal ini disebabkan oleh makin kerasnya aspal dalam campuran, sebagai akibat dari penambahan bitumen Liquid asbuton yang keras, sehingga proses pemadatan relatif menjadi lebih sulit dan menghasilkan rongga antara butiran yang lebih besar. Selanjutnya, nilai VMA yang lebih besar tersebut menyebabkan diperolehnya nilai VFB yang lebih kecil, oleh karena VFB merupakan persentase volume aspal efektif terhadap VMA.

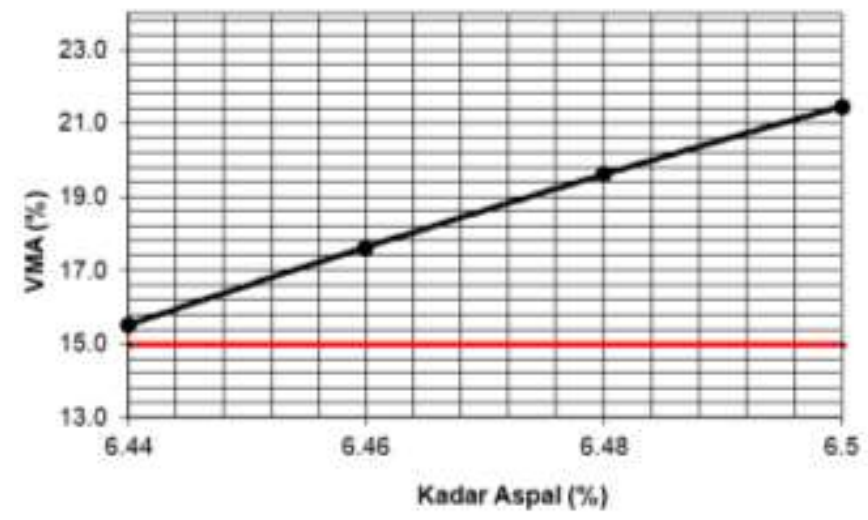

\section{Gambar 5. Hubungan Kadar Plastik + Aspal Terhadap VMA}

Gambar 5 tersebut diatas menjelaskan bahwa VMA mengalami penurunan seiring dengan meningkatnya penambahan serpih sampah plastik kedalam campuran AC-BC, hal terlihat dari kadar aspal 6,50\% dengan penambahan 1\% semakin turun sampai dengan kadar aspal 6,44\% penambahan $6 \%$ plastik.

\section{f. Rongga terisi aspal (Void Filled Bitumen)}

VFB adalah rongga terisi aspal yang merupakan bagian dari VMA yang terisi oleh kandungan aspal efektif (Bina Marga, 1999). Sedang kadar aspal efektif adalah kadar aspal total dikurangi jumlah aspal yang diserap oleh agregat. Kadar aspal efektif akan menyelimuti permukaan agregat bagian luar yang pada ahirnya akan menentukan kinerja campuran aspal.

Pada Gambar 6 diatas menjelaskan bahwa VFB mengalami peningkatan seiring dengan meningkatnya penambahan serpih sampah plastik kedalam campuran AC-BC. Penambahan serpih sampah plastik kedalam campuran aspal AC-BC, akan mengakibatkan semakin mengecilnya rongga dalam campuran akibat berat jenis aspal dengan plastik yang semakin meningkat. Bertambahnya nilai VFB dalam penelitian ini diakibatkan oleh mengecilnya rongga dalam campuran (VIM) yang merupakan bagian dari pembagi dalam menentukan nilai VFB. Selain hal tersebut, penelitian ini juga memberikan gambaran bahwa dengan masuknya serpih sampah plastik 
kedalam campuran, penyerapan aspal kedalan pori material (absorbsi) akan semakin mengecil. Dengan demikian kadar aspal efektif akan meningkat seiring kenaikan nilai VFB. Sehingga dengan penambahan serpih sampah plastik kedalam campuran AC-BC dapat menjadikan kinerja campuran semakin membaik (Zultan dan Nawir, 2019).

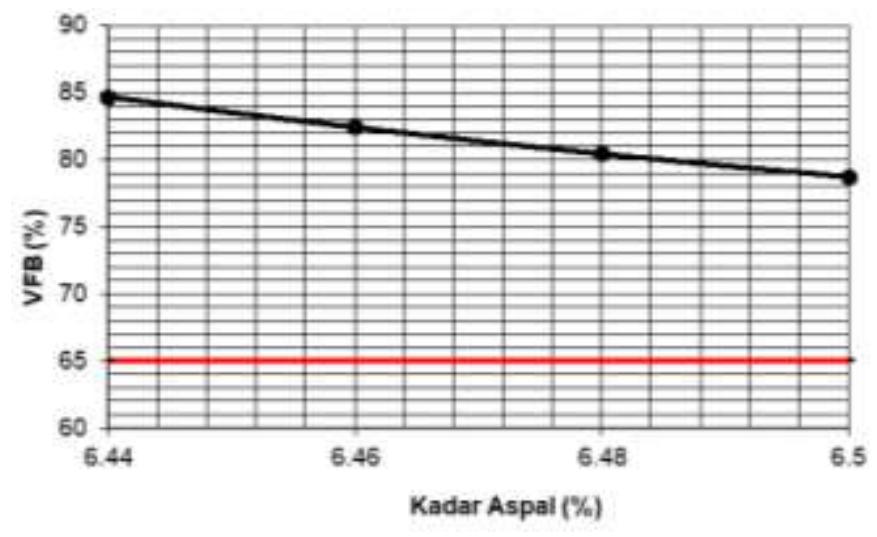

Gambar 6. Hubungan Kadar Plastik + Aspal Terhadap VFB

\section{g. Pengujian Indeks Kekuatan Sisa}

Pengujian Indeks Kekuatan Sisa atau Pengujian perendaman Marshall adalah metode untuk mengetahui ketahanan atau keawetan campuran terhadap suhu, cuaca dan air hingga hilangnya ikatan antara aspal dan butiran agregat (ASTM D-1075. 2010). Nilai IKS campuran didapat dari hasil perbandingan nilai stabilitas benda uji hasil rendaman 1 × 24 jam dengan nilai stabilitas benda uji standar (hasil rendaman 30 menit) pada temperatur $60^{\circ} \mathrm{C}$. Nilai Indeks Kekuatan Sisa (IKS) dipengaruhi oleh tingkat kelekatan agregat dengan aspal yang antara lain tergantung pada bentuk dan jumlah pori agregat, sifat reologi aspal, kadar aspal, kepadatan, kandungan rongga dan gradasi agregat.

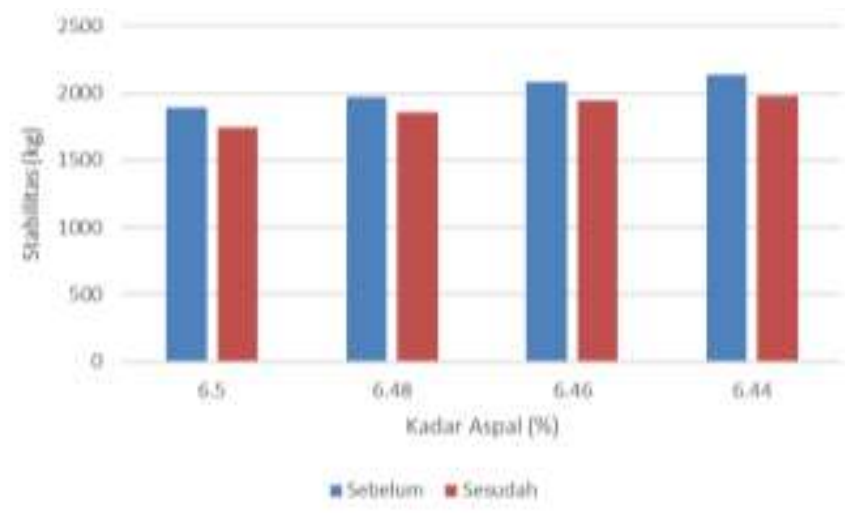

Gambar 7. Perbandingan Indeks Kekuatan Sisa pada tiap proporsi campuran

Dari hasil penelitian penulis, campuran dengan Liquid asbuton lebih tahan terhadap perubahan cuaca, temperatur dan air. Hasil penelitian pada gambar 7 diatas menerangkan bahwa dengan serpih sampah plastik yang dimasukkan kedalam campuran AC-BC, dapat menambah kemampuan campuran dalam melawan cuaca buruk sekalipun. Hal ini dibuktikan dengan, dimana kemampuan akan stabilitas campuran yang mengandung plastik tetap sesuai dengan spesifikasi setelah perendaman $24 \mathrm{jam}$ pada suhu $60^{\circ} \mathrm{C}$. Adapun kekuatan sisa setelah mengalami perendaman 24 jam maka pada kadar plastik $0 \%$ (kadar aspal 6,50 \%) sisa kemampuan stabilitasnya 92,3 \%, pada 
kadar plastik $2 \%$ (kadar aspal 6,48 \%) sisa kemampuan stabilitasnya 94,3\%, pada kadar plastik 4\% (kadar aspal 6,46\%) sisa kemampuan stabilitasnya 93,3\%, pada kadar plastik $6 \%$ (kadar aspal $6,44 \%$ ) sisa kemampuan stabilitasnya $92,5 \%$.

\section{h. Rongga dalam campuran pada kepadatan membal (refusal)}

Pengujian Vim Refusal (Kepadatan mutlak) dilakukan untuk mengetahui kandungan rongga dan kepadatan mutlak (Bina Marga, 1999) sebagai simulasi dari pemadatan lanjutan oleh lalu lintas yang digambarkan dengan berubahnya nilai rongga dalam campuran dalam campuran (VIM) yang dilakukan dengan proses pemadatan / penumbukan $2 \times 400$ perbidang. Nilai VIM pada pemadatan standar (Marshall 2x75 tumbukan), akan berkurang nilainya akibat pemadatan Refusal (pemadatan dengan alat getar listrik/Marshall 2x400 tumbukan). Keterbatasan metode Marshall adalah ketergantungan terhadap kepadatan setelah dilalui kendaraan untuk mencapai rongga udara dalam campuran beraspal AC-BC yang disyaratkan dengan persyaratan spesifikasi pada minimal 2,5\% (Zultan dan Nawir, 2019)

Pada tabel 4 diatas di jelaskan bahwa rongga dalam campuran pada kepadatan membal (VIM Refusal), dapat dicapai sesuai yang dianjurkan spesifikasi Bina Marga 2018 yaitu minimal 2\% walaupun mengalami penurunan seiring dengan penambahan serpih sampah plastik kedalam campuran AC-BC. Penambahan serpih sampah plastik kedalam campuran AC-BC, memberikan pengaruh terhadap nilai VIM yang cenderung mengecil. Namun dalam pengujian di laboratorium pada 400 tumbukan perbidang, hasilnya belum melampaui ambang spesifikasi yang diizinkan. Pada konsentrasi kadar plastik $6 \%$ terhadap berat aspal VIM refusal mendekati ambang spesifikasi namun belum dapak dikatakan lebih kecil dari yang dianjurkan karena nilainya 3,4\%, dibanding dengan yang dianjurkan minimal $2 \%$.

\section{Kesimpulan}

1. Hasil penelitian menunjukkan bahwa penggunaan Liquid Asbuton dengan penambahan serpih plastik 6\%, dalam campuran aspal beton AC-BC dapat meningkatkan kinerja Stabilitas campuran aspal dari $1887,42 \mathrm{Kg}$ menjadi $2138,62 \mathrm{Kg}$ dengan kadar aspal optimun $6,50 \%$. Penambahan plastic pada Liquid asbuton menyebabkan penetrasi aspal menjadi lebih kecil (lebih keras) dan viskositas aspal menjadi lebih besar (lebih kental) akibat bertambahnya unsur kimia logam yang terkandung dalam Liquid asbuton. Sehingga menyebabkan kelekatan terhadap aggregat akan semakin kuat.

2. Substitusi Serpih sampah plastik HDPE terhadap Liquid Asbuton dapat memberikan pengaruh terhadap karakteristik campuran aspal beton AC-BC pada konsentarasi maksimum $6 \%$ terhadap berat aspal yaitu :

$>$ Meningkatkan stabilitas campuran yaitu meningkatkan kemampuan campuran (konstruksi jalan) aspal beton AC-BC untuk memikul beban lalulintas sampai terjadi kelelehan plastis.

$>$ Menurunkan nilai Flow campuran yakni mengurangi kelenturan namun pengurangan itu masih tetap dalam ambang Spesifikasi pada kadar plastik 6\% terhadap berat aspal.

> Meningkatkan nilai Marshall Quotient (MQ). Keberadaan plastik kedalam campuran AC$\mathrm{BC}$, dapat meningkatkan kemampuan konstruksi jalan dalam menerima beban, namun konstruksi tersebut masih fleksibel dan lentur.

$>$ Menurunkan nilai VIM (memperkecil pori pada campuran), lebih meningkatkan keawetan pada konstruksi jalan tanpa terjadi deformasi plastis (bleeding).

$>$ Menurunkan nilai VMA (rongga diantara agregat), sehingga konstruksi jalan dapat lebih awet.

$>$ Menaikkan nilai VFB (rongga terisi aspal), meningkatkan kadar aspal efektif yang akan menyelimuti material dan menentukan kinerja campuran dalam suatu konstruksi. 
$>$ Meningkatkan Stabilitas Marshall sisa setelah perendaman 24 jam pada suhu $60^{\circ} \mathrm{C}$, yaitu dapat menambah kemampuan campuran dalam melawan kondisi cuaca buruk.

$>$ Konstruksi jalan mampu menerima pembebanan kendaraan setelah masa layanan yang telah dibuktikan melalui pengujian kepadatan membal (refusal) marshal 400 tumbukan.

3. Substitusi Serpih sampah plastik terhadap Liquid Asbuton dapat menghemat penggunaan/pemakaian aspal sebesar $6 \%$ terhadap berat aspal yang digunakan dalam campuran aspal beton AC-BC.

\section{Daftar Pustaka}

AASHTO.1978. Standard Specifications for Transportation Materials and Methods of Sampling and Testing. Washington, D.C.

ASTM D-1075. 2010. Standard Test Method for Effect of Wateron Compressive Strength of Compacted Bituminous Mixtures. United States.

David W. Oxtoby,, dkk, 2008. Prinsip-prinsip Kimia Modern, Edisi Keempat Jilid Dua. Penerbit Erlangga, Jakarta.

Direktorat Jenderal Bina Marga. 1999. Perencanaan Campuran Beraspal Dengan Pendekatan Kepadatan Mutlak, Yayasan Badan Penerbit Pekerjaan Umum, Jakarta.

Direktorat Jenderal Bina Marga. 2018. Spesifikasi Umum Jalan dan Jembatan, Pusat Litbang Jalan dan Jembatan, Badan Penelitian dan Pengembangan, Jakarta.

Kurniawan, E. dan Nasrun, 2014. Karakterisasi Bahan Bakar Dari Sampah Plastik Jenis High Density Polyethelene (HDPE) Dan Low Density Polyethelene (LDPE). Jurnal Teknologi Kimia Unimal 3 : 2(November 2014), hal. 41-52. E-ISSN 2580-5436

R. Anwar Yamin, Siegfried, 2012. Penanganan Dan Pemanfaatan Aggregat Lokal Dan Substandard Untuk Pekerasan Jalan. Pustlitbang Jalan dan Jembatan, Jakarta.

R. Anwar Yamin, 2002. Petunjuk Umum, Manual Pekerjaan Campuran Beraspal Panas. Pustlitbang Prasarana Transportasi, Jakarta.

RSNIM-01-2003. Metode Pengujian Campuran Beraspal Panas Dengan Alat Marshall. Pustran- Balitbang Pekerjaan Umum, Bandung.

Zultan M., A., 2017, "Analisis Karakteristik Campuran Aspal Beton (AC-BC) Dengan Penambahan Serpih Sampah Plastik" dalam Prosiding Simposium Forum Studi Transportasi antar Perguruan Tinggi ke-20 (Universitas Hasanuddin, Makassar, 4 - 5 November 2017)

Zultan M., A., Bakri, M. D., Nawir, D., 2018, "Karakteristik Aspal Beton (AC-BC) Pada Material Daur Ulang Menggunakan Pasir Pantai Dengan Penambahan Serpih Sampah Plastik" dalam Prosiding Simposium Forum Studi Transportasi antar Perguruan Tinggi ke-20 (Universitas Brawijaya, Malang, 19 - 20 Oktober 2018) 
Setrayani, A. Noor T., Janadi, W., 2018,“ Pengaruh Lama Perendaman Terhadap Karakteristik Lapisan Aus Laston Menggunakan Agregat Terselimut Limbah Plastik LDPE” dalam Prosiding Konferensi Nasional Teknik Sipil 12 (Batam, 18-19 September 2018)

Zultan M., A., Nawir, D., 2019,“Studi Experimental Karakteristik Campuran Aspal Beton (ACWC) Menggunakan Liquid Asbuton Dengan Penambahan Serpih Sampah Plastik" dalam Prosiding Konferensi Nasional Teknik Sipil 13 (Banda Aceh, 19-20 September 2019) 